Obrazhei Olha. Adaptation of folk games to accelerated swimming training of junior schoolchildren in outdoor swimming pools or reservoirs. Pedagogy and Psychology of Sport. 2020;6(3):19-32. elSSN 2450-6605. DOI http://dx.doi.org/10.12775/PPS.2020.06.03.002 https://apcz.umk.pl/czasopisma/index.php/PPS/article/view/PPS.2020.06.03.002

https://zenodo.org/record/4037452

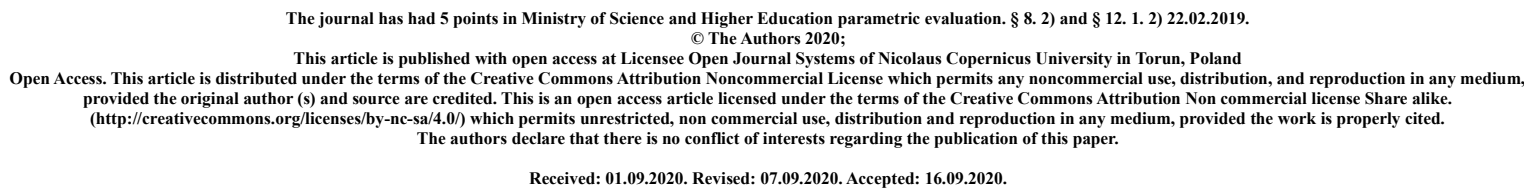

\title{
ADAPTATION OF FOLK GAMES TO ACCELERATED SWIMMING TRAINING OF JUNIOR SCHOOLCHILDREN IN OUTDOOR SWIMMING POOLS OR RESERVOIRS
}

\section{Olha Obrazhei}

Lesya Ukrainka Eastern European National University

obrik102119@ukr.net

https://orcid.org/0000-0002-1057-3908

\section{Abstract}

The goal of the research was to test the effectiveness of the introduction of adapted Ukrainian folk games into the methodology of teaching swimming to junior schoolchildren in outdoor swimming pools or reservoirs.

Methodology: theoretical analysis and summary of scientific and methodological literature, pedagogical observations, testing, pedagogical experiment, methods of mathematical analysis and statistics.

Results. To assess the children's swimming fitness during the research, we developed a set of swimming tests. The results showed that we were able to significantly reduce a fear of water in junior schoolchildren by $28 \%(\mathrm{p}<0.001)$. The smallest increase in rating was obtained in the tests "underwater breath hold" and "starfish float" $-25 \%(\mathrm{p}<0.05)$ each, "putting a face in the water" $-27 \%(\mathrm{p}<0.001)$, and "gliding and arm movements" $-30 \%(\mathrm{p}$ $<0.01)$. The highest rate of improvement was found in tests that measure coordination in swimming $-35 \%(\mathrm{p}<0.001)$ and gliding and leg movements $-36 \%(\mathrm{p}<0.05)$. The index of schoolchildren's swimming training increased by 0.31 during the research. 
Conclusion. The obtained test results and index of swimming training (0.85) indicate the effectiveness of the introduction of adapted Ukrainian folk games into the methodology of teaching swimming to junior schoolchildren in outdoor swimming pools or reservoirs.

Key words: swimming, Ukrainian folk games, junior schoolchildren.

Introduction. Statistics of deaths in water bodies in Ukrainian in the summer period are constantly growing. Unfortunately, the number of our compatriots who can swim is not increasing. Therefore, the issue of swimming training continues to be relevant.

Opinions vary on the orientation of the methodology of teaching swimming, but most researchers draw attention to the need for the introduction of modern pedagogical technologies, the creation of a set of scientific and methodological support, and the appropriate conditions for the organization of life safety in the process of swimming training.

The issue of swimming training has been highlighted in numerous works of such scientists as N. Bulgakova [1]; L. Makarenko [2]; T. Osokina [3]; M. Savchenko [4]; V. Parfenov [5]; O. Skaliy [6]; I. Honchar [7]; E. Shmareva [8]; D. Kachurovskii [9] and others.

At the same time, the analysis of scientific researches shows the lack of a sound methodology for overcoming a fear of water at swimming lessons as well as methodological manuals on prevention and overcoming of aquaphobia, which leads to certain difficulties and disruption of the logical sequence of swimming training. The results of a preliminary questionnaire survey of junior schoolchildren who did not master swimming [10] showed that the reason for their unwillingness to learn to swim was the consequences of unsuccessful swimming in outdoor swimming pools or reservoirs, when a child fell into the water and swallowed some water, when a boat overturned; failure to use supporting aids, such as inflatable vests, swimming boards and balls, arm ruffles and other means properly, violations of methods of teaching swimming by parents or coaches. Children learn about the dangers of swimming from their parents, who retell the tragic events associated with outdoor swimming pools or reservoirs in the presence of children. The cause of children's fears is also watching horror movies whose plots focus on the tragedies in outdoor swimming pools or reservoirs, accompanied by bloody scenes and death.

Thus, studies have shown that one of the obstacles to effective swimming training is the fear of water and the conditions of outdoor swimming pools or reservoirs. In the context of this problem, scientists $[1,3,4,6]$ commonly recommend using a game-like method when teaching swimming to children of junior school age, allowing children not to focus their 
attention on their fears, but on performing a motor action.

In modern conditions of the development of Ukraine, the use of national games in the formation of junior schoolchildren's personalities, their motor abilities and skills acquires special value. Historical ethnographic studies conducted by Ye. Prystupa [11], A. Volchynskyi [12], and A. Tsos [13] show that Ukrainian folk games are very diverse and most of them have established themselves in the calendar rituals, so the researchers use the term "folk game", which provides for human play activity in accordance with the national traditions of the people.

Games, if used systematically, contribute to improving health and provide sufficient physical activity for junior schoolchildren. They satisfy the need of the child's body for movement, contribute to the enrichment of the child's motor experience. With the help of games, children develop such important physical qualities as strength, physical alertness, agility, and endurance.

Along with the main task - the improvement of the human body, games significantly affect the spiritual world: the world of emotions, aesthetic tastes, and ethical aspects of the personality. That is why the researchers of this problem $[11,12,13,19]$ emphasized the special importance of folk games as a means of all-round education of the child.

A. Volchynsky [12] considers the folk game not only as a means of physical education, but also as a means of acquainting modern children with national culture, because from the point of view of history, games reflect the traditions of our people, everyday life, theoretical judgments and climatic living conditions. All this, according to the researcher, creates the conditions for the formation of children's interest in the national physical culture and the need to exercise independently.

The important role of Ukrainian folk games in the all-round development of children is pointed out in the works of such authors as V. Levkiv [14], O. Onopriienko [15], and S. Mudryk [16], who highlight the problem of the lack of Ukrainian folk games in everyday life of schoolchildren.

The results of a preliminary questionnaire survey [10] and the analysis of scientific and methodological works showed that the use of old, traditional forms, tools and methods of teaching swimming to junior schoolchildren does not make it possible in modern conditions to solve the problem quite well. Thus, this proves the great social and pedagogical significance of the use of Ukrainian folk games in teaching swimming to junior schoolchildren, which determined the choice of the research topic.

The goal of the research was to test the effectiveness of the introduction of adapted 
Ukrainian folk games into the methodology of teaching swimming to junior schoolchildren in outdoor swimming pools or reservoirs.

Materials and research methods. The research was done at the swimming workouts conducted at the summer health camp "Chervoni vitryla" (Skadovsk) during August 2019. The session lasted 14 days. The study engaged 20 schoolchildren (11 girls and 9 boys) aged 8 to 9 .

Swimming workouts were held twice a day, except for the day of children's arrival and the last day of their stay in the health camp, on these days workouts were held once a day.

A preliminary analysis of the levels of manifestation of physical qualities and swimming fitness revealed insignificant differences between boys and girls at this age, which made it possible to group them together. Swimming workouts were held twice a day, except for the day of the children's arrival and the last day of their stay in the health camp, when the classes were held once a day. Swimming workouts were held from 10.00 to 12.00 a.m. and from 4.00 to 6.00 p.m. in the Black Sea, with special attention paid to the children's safety and injury prevention. Medical supervision was carried out by medical staff of the summer health camp.

To assess the children's swimming fitness during the research, we developed a set of swimming tests, which included: fear of water; putting a face in the water; squats in the water; water jumps; underwater breath hold; ability to do the starfish float; ability to push off and glide; ability to glide and do leg movements; ability to glide and do arm movements; and coordination in swimming.

To diagnose the formation of swimming skills, we used a five-score assessment scale [17]. The maximum possible number of scores that a junior schoolchild could get for the correct performance of ten swimming tests was 50 .

In order to test the effectiveness of the introduction of adapted Ukrainian folk games in teaching swimming to junior schoolchildren in the summer health camp, we calculated the learning index. According to the test results, the learning index was calculated by the formula of V. Bespalko [18]:

$$
\mathrm{K}=\frac{Q}{N}
$$

where $\mathrm{Q}$ is the number of scores received by junior schoolchildren for tests; $\mathrm{N}$ - the maximum possible number of scores.

The performance of the tests was considered sufficient if the index $\mathrm{K}$ was not less than 0.7 , which corresponds to $70 \%$. 
The obtained results were recorded in individual protocols and processed using methods of mathematical statistics.

Research results. The notion of game is very broad and multifaceted, so there are many approaches to its definition:

- a kind of game activity, based on creative, physical actions motivated by the plot (theme, idea) of the game, partially limited by the rules, these actions are determined by changing game circumstances, as well as the focus on reaching the goal [16];

- specific motor activity according to the established rules, aimed at achieving victory [11];

- a historically formed social phenomenon, a special type of activity of the child, where phenomena of the surrounding world are reflected creatively, directly or indirectly [12].

The analysis of various approaches made it possible to formulate the basic definition of the notion of game: it is a certain activity of the child aimed at satisfying his/her interests and solving educational problems.

As a result of interpretation and generalization of the literature data $[3,4,13,16]$ and the data of our study, we adapted Ukrainian folk games (with elements of combined developing exercises, walking, running, and jumping) to the accelerated swimming training of junior schoolchildren in outdoor swimming pools or reservoirs.

The main movements that were part of the ground-based game were replaced by the initial swimming movements in the water (immersion in water; squats in the water; jumping into the water; the ability to push and glide; the ability to swim in coordination, and others). For example, if players of the Ukrainian folk game are to march on the spot, swinging their arms back and forth, then in the aquatic environment we ask children from a supine position to walk just on their hands on the bottom of the pool, with their faces immersed in the water. The adaptation of Ukrainian folk games to the accelerated swimming lessons of junior schoolchildren in outdoor waters is presented in greater detail in Table 1. 
Adapting Ukrainian folk games to improve the swimming skills of young schoolchildren in outdoor swimming pools or reservoirs

\begin{tabular}{|c|c|c|}
\hline $\begin{array}{l}\text { Main movement patterns in } \\
\text { games out of the water }\end{array}$ & $\begin{array}{l}\text { Main movement patterns in } \\
\text { games in the water }\end{array}$ & $\begin{array}{c}\text { Names of folks games } \\
\text { involving movement }\end{array}$ \\
\hline $\begin{array}{l}\text { Holding hands, the children } \\
\text { form a circle that moves to the } \\
\text { right and then to the left. }\end{array}$ & $\begin{array}{l}\text { Holding hands, the children } \\
\text { form a circle and take turns } \\
\text { exhaling into the water. } \\
\text { Holding hands, the children } \\
\text { form a circle, and in turn let go } \\
\text { of each other's hands and } \\
\text { perform the "Float" or "Star" } \\
\text { exercises. }\end{array}$ & $\begin{array}{l}\text { "Father and children } \\
\text { "(“Bat'ko i dity”), "Poppy" } \\
\text { ("Mak"), "Adam and Eve" } \\
\text { (“Adam i Yeva"), "Broken } \\
\text { ball" ("Rozbyte } \\
\text { yayechko"), "Shevchik" } \\
\text { (“Shevchyk"), "Oh, curl } \\
\text { cucumbers" ("Oi, vyitesia } \\
\text { ohirochky"), "Cat and } \\
\text { mouse" ("Kit i mysha"), } \\
\text { "Pike" (“shchupak"), } \\
\text { "Swings" ("Hoidalky"). }\end{array}$ \\
\hline $\begin{array}{l}\text { Players form pairs in a circle. } \\
\text { Move in opposite directions } \\
\text { first to the right, then to the } \\
\text { left. }\end{array}$ & $\begin{array}{l}\text { Players take the position of } \\
\text { resistance lying on their } \\
\text { stomachs, in shallow water, in } \\
\text { rows of two, facing each other. } \\
\text { They carry out the "Scissors"; } \\
\text { "Fountain" or "Crocodile" } \\
\text { exercises. }\end{array}$ & $\begin{array}{l}\text { "Riders" ("Vershnyky"), } \\
\text { "Trifle" ("Dribushka"), } \\
\text { "Wheelbarrows" } \\
\text { ("Tachky"). }\end{array}$ \\
\hline Performing jumps. & $\begin{array}{l}\text { Performing high jumps or long } \\
\text { jumps in the water with faces } \\
\text { immersed, performing the } \\
\text { "Diving" exercise. }\end{array}$ & $\begin{array}{l}\text { "Buckwheat" ("Hrechka"), } \\
\text { "In the river hop" ("U } \\
\text { richku hop"), "Rooster" } \\
\text { ("Pivnyk"). }\end{array}$ \\
\hline $\begin{array}{l}\text { The players stand in pairs, } \\
\text { facing each other, and are lifted } \\
\text { aloft with their arms crossed. } \\
\text { The last pair passes under the } \\
\text { hands of all other pairs and } \\
\text { becomes the first, followed by } \\
\text { the pair that was the } \\
\text { penultimate, and so on. }\end{array}$ & $\begin{array}{l}\text { The players stand in pairs } \\
\text { facing each other, and are lifted } \\
\text { aloft with their arms crossed. } \\
\text { One player of the pair standing } \\
\text { at the end swims under the } \\
\text { arms of all other pairs } \\
\text { performing the exercise } \\
\text { "gliding on the chest" or } \\
\text { "gliding on the back" with or } \\
\text { without support, and becomes } \\
\text { the first, followed by the } \\
\text { second of the pair and so on. }\end{array}$ & $\begin{array}{l}\text { "Bridge" (“Mist”), "Long } \\
\text { vine" (“Dovha loza"), } \\
\text { "Stump" (“Pen”"). }\end{array}$ \\
\hline $\begin{array}{l}\text { In the middle of the site draw } \\
\text { two parallel lines. Players are } \\
\text { divided into two teams, which } \\
\text { are located along the lines. The } \\
\text { team named by the manager } \\
\text { chases the other team. After } \\
\text { counting the players who have }\end{array}$ & $\begin{array}{l}\text { Players are divided into two } \\
\text { teams, which are located along } \\
\text { the track. The team named by } \\
\text { the leader catches up with the } \\
\text { other team by performing the } \\
\text { breaststroke - legs - and the } \\
\text { scissor-stroke exercise with or }\end{array}$ & $\begin{array}{l}\text { "The Wolf and the goats" } \\
\text { ("Vovk i kozy"), "Panas" } \\
\text { ("Panas"), "Day and night" } \\
\text { ("Den' ta nich"). }\end{array}$ \\
\hline
\end{tabular}




\begin{tabular}{|c|c|c|}
\hline $\begin{array}{l}\text { been caught, the teams return to } \\
\text { their seats, and the game is } \\
\text { repeated. }\end{array}$ & without a support. & \\
\hline $\begin{array}{l}\text { All players except one form a } \\
\text { column, holding each other by } \\
\text { the waist or the shoulders. } \\
\text { At the command of the leader, } \\
\text { the player who did not enter the } \\
\text { column runs to the last one in } \\
\text { the column, who tries to escape } \\
\text { to the opposite side of the } \\
\text { column and stand in front of } \\
\text { the guide. }\end{array}$ & $\begin{array}{l}\text { All players except one form a } \\
\text { chain, taking each other by the } \\
\text { belt, walking on the bottom of } \\
\text { the pool in a straight line, in a } \\
\text { circle or on some other curved } \\
\text { line. At the command of the } \\
\text { leader, the player who did not } \\
\text { enter the chain performing the } \\
\text { "arms breaststroke on the } \\
\text { chest" exercise swims to the } \\
\text { last one in the column, who } \\
\text { tries to escape by performing } \\
\text { the "arms breaststroke" } \\
\text { exercise on the opposite side of } \\
\text { the chain and stand in front of } \\
\text { the guide. }\end{array}$ & $\begin{array}{l}\text { "Hawk" ("Yastrub"), "Gray } \\
\text { cat" ("Siryi kit"). }\end{array}$ \\
\hline $\begin{array}{l}\text { Children stand in a circle, using } \\
\text { a counter to determine the one } \\
\text { who is to chase, and the ones } \\
\text { who are to flee. The one } \\
\text { indicated by the counter chases } \\
\text { the other participants in the } \\
\text { game. }\end{array}$ & $\begin{array}{l}\text { Children standing in a circle, } \\
\text { using a counter to determine } \\
\text { which one is to chase the } \\
\text { others, and all the other players } \\
\text { are allowed only to swim } \\
\text { according to the "Swimming in } \\
\text { coordination" exercise. }\end{array}$ & $\begin{array}{l}\text { "Sausage" (“Kovbasa”), } \\
\text { "Peter, where are you?" } \\
\text { (“Petre de ty?”), } \\
\text { "Laughter" (“Rehit”), } \\
\text { "Zaporozhets on the Sich" } \\
\text { (“Zaporozhets na Sichi”). }\end{array}$ \\
\hline
\end{tabular}

The main swimming movements used in Ukrainian folk games for the accelerated swimming lessons of junior schoolchildren were performed from different starting positions: standing, from a squat, with movable and solid support, at a small $(30 \mathrm{~cm})$ depth, from an unsupported position in a deep place $(60 \mathrm{~cm})$, with equipment (swimming circles, "bagry", "cats", cable, "nudly", inflatable balls, gymnastic hoops, etc.) and without them, with the support and without the support of a female partner by a male partner.

The magnitude of the load was adjusted (upwards or downwards) by changing the amplitude of the movements, the pace, the rhythm, the complexity of the coordination and number of repetitions.

Based on the topic of our study, we have developed a classification of Ukrainian folk games in terms of the possibility of using them in the accelerated swimming lessons of junior school children (fig. 1). 
Fig. 1. Classification of Ukrainian folk games in the system of teaching swimming to junior schoolchildren

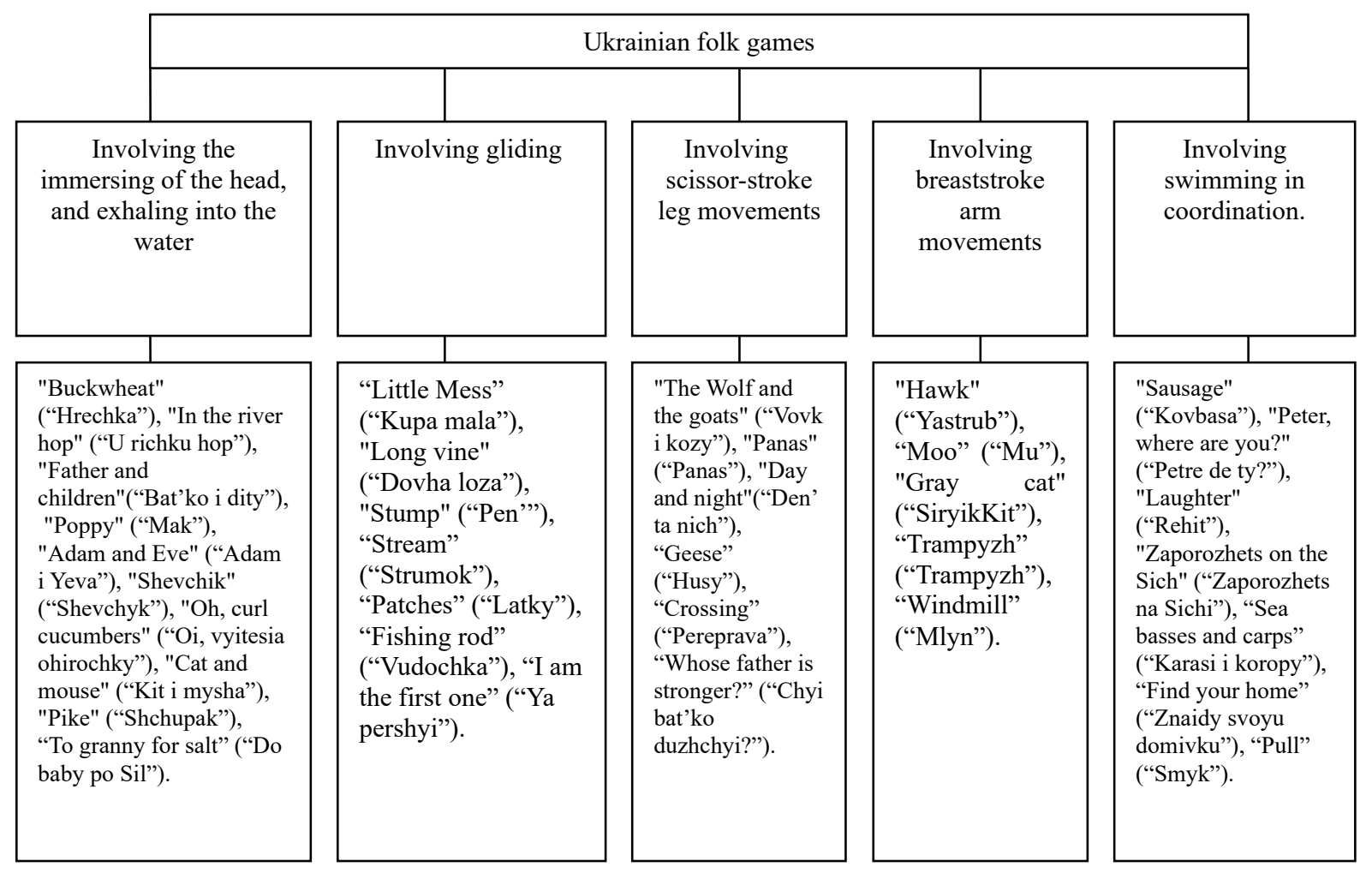

Adapted Ukrainian folk games for junior schoolchildren's accelerated swimming lessons were introduced into the training process of the "Chervoni Vitryla" camp and were utilized taking three stages of camp modification into consideration -organizational, basic, and final.

The organizational period involved the first two days, during which three training sessions were held. The purpose of the classes was to acquaint the children with the conditions of the aquatic environment, developing in them a comfortable and positive attitude psychologically and emotionally to activities in the water.

In accordance with the goal of this period, we set the following tasks: to acquaint children with the conditions and rules of conduct in bathing and swimming areas; to arouse in children a desire to learn to swim, and to educate them about how to act in the water; to teach the children to go into the water without being afraid, and to be in water up to the level of their chest, their neck, their chin, and their nose, and to play independently; to walk, run, jump, and crawl in shallow water; to teach children to move their legs in a scissor-stroke, sitting on the shore or in shallow water. The following games were used to achieve the goals and objectives that had been established: "Poppy" ("Mak"), "Father and children"(“Bat'ko i 
dity"), "Peter, where are you?" (“Petre de ty?”), “Geese” (“Husy”), "The Wolf and the goats" ("Vovk i kozy"), "Wonder whale" ("Chudo-yudo-rybe-kyu”), "Ship" ("Korabel”), "Who is the first one?" (“Khto pershyi?"), "Crossing" ("Pereprava"), "Crocodile” ("Krokodyl”), "Windmill” ("Mlyn"), "Panas" ("Panas"), "Cat and mouse" (“Kit i mysha"), "Long vine" ("Dovha loza"), "Battle with balls" ("Bytva kul'kamy”), "Herons" ("Chapli”), "Seagull” ("Chaika"), "To granny for salt" ("Do baby po sil"), "Whose father is stronger?" ("Chyi bat'ko duzhchyi?"), "Scissors" ("Nozhytsi”), "Stump" (“Pen”), "Buckwheat" ("Hrechka”), "Sea Basses and Carps" (“Karasi i koropy”), “To the goal” (“Do tsili”) etc.

The main period covered the next nine days, during which eighteen classes were held. The purpose of this stage was to develop the children's confidence and activity in the aquatic environment, and the formation of basic skills and abilities during the process of learning the basic elements of swimming.

The main tasks of this stage were: to educate children in the desire for activity and independence when moving and playing in water up to their waist or chest; to teach them to have the confidence to put their faces under water, and then to place their head under water; to begin opening their eyes in the water; to teach them to to inhale and exhale properly while standing still; to master the skill of exhaling into the water, while immersed to the chin, the nose, and the eyes, lowering the face into the water completely; to master exercises of inhaling and holding their breath; to form skills of floating and lying on the water from the starting position on the chest or back ("jellyfish", "float"); to start learning to glide on their chest and back; to perform leg movements, to move their legs in a scissor-stroke, lying on the ground and in the water. In order to achieve the tasks at this stage, the following games were used "Father and children"("Bat'ko i dity"), "Day and night" ("Den' ta nich”), "In the river hop" ("U richku hop"), "Turtle" ("Cherepakha"), "Pumpkin" ("Harbuz"), "Dolphin" ("Del'fin"), "Little bee" ("Bdzhilka"), "Field girl" ("Podolyanochka"), "Fishing rod" ("Vudochka"), "Hawk" ("Yastrub"), "Who is the first one?" ("Khto pershyi?”), "Shevchik" ("Shevchyk"), "Bicycle” (“Velosyped”), "Little star" (“Zirochka"), "Adam and Eve" (“Adam i Yeva"), "Bridge" ("Mist”), "Rooster" ("Pivnyk"), "Gray Cat" (“Siryi kit”), "Panas" (“Panas”), “Oak” (“Dub”), "Be careful!” (“Bud' uvazhnym!”), “Stream” (“Strumochok”), "Zaporozhets on the Sich" ("Zaporozhets na Sichi”) and others.

The final stage lasted for the next three days of the camp shift, during which five classes were held. The main purpose of this stage was to ultimately overcome psychological anxiety in an aquatic environment, and to improve the swimming skills which had been acquired. 
This stage included: increasing awareness about the importance of swimming, and the rules of conduct on the water; improving the ability of children to confidently dive into the water headfirst; to reinforce their ability to open their eyes under the water without being afraid; to navigate underwater, getting various objects from the bottom of the pool; to improve children's ability to exhale into the water vigorously and completely (breathing in through the mouth and breathing out through the nose and mouth); to master gliding without anything in their hands while holding their breath, as well as when exhaling into the water; to continue to develop the ability and skills of floating and lying on the water ("float", "jellyfish", "star"), gliding with an object or a swimming board in their hands on their chest and on their back; to improve their leg movement coordination by executing the breaststroke and scissor-strokes, holding their breath while staying in one place; and to perform breaststrokes and scissorstrokes while lying on their backs. To achieve this goal at this stage, the following games were used: "Broken ball" ("Rozbyte yayechko"), "Blind man's bluff" ("Zhmurky"), "Buckwheat" (“Hrechka"), "Little mess" (“Kupa mala”), "To the goal” (“Do tsili”), "Bringing a watermelon” (“Vezemo kavun”), "Little star" (“Zirochka”), "Hold!” (“Utrymaye!”), "Fish and net" ("Ryba i merezha"), "Sea basses and carps" ("Karasi i koropy”), "Quick three" ("Shvydka triika"), "Find quick" ("Skorishe znaidy"), Brook "Strumochok", "Races on the circles" ("Honky na kolakh"), "Diving Ducks" ("Kachky-Nyrky”), "Ball Underwater" (“Myach pid Vodoyu”), "Sausage" (“Kovbasa”), "Peter, where are you?" (“Petre de ty?”), "Laughter" ("Rehit”),"Zaporozhets on the Sich" (“Zaporozhets na Sichi”), "Find your home” ("Znaidy svoyu domivku”) and others.

In order to test the effectiveness of the system that had been developed for accelerated swimming training using folk games during the camp shift, we performed control tests involving ten exercises. The results of the junior high school students'swimming skills tests are shown in Figure 2. 


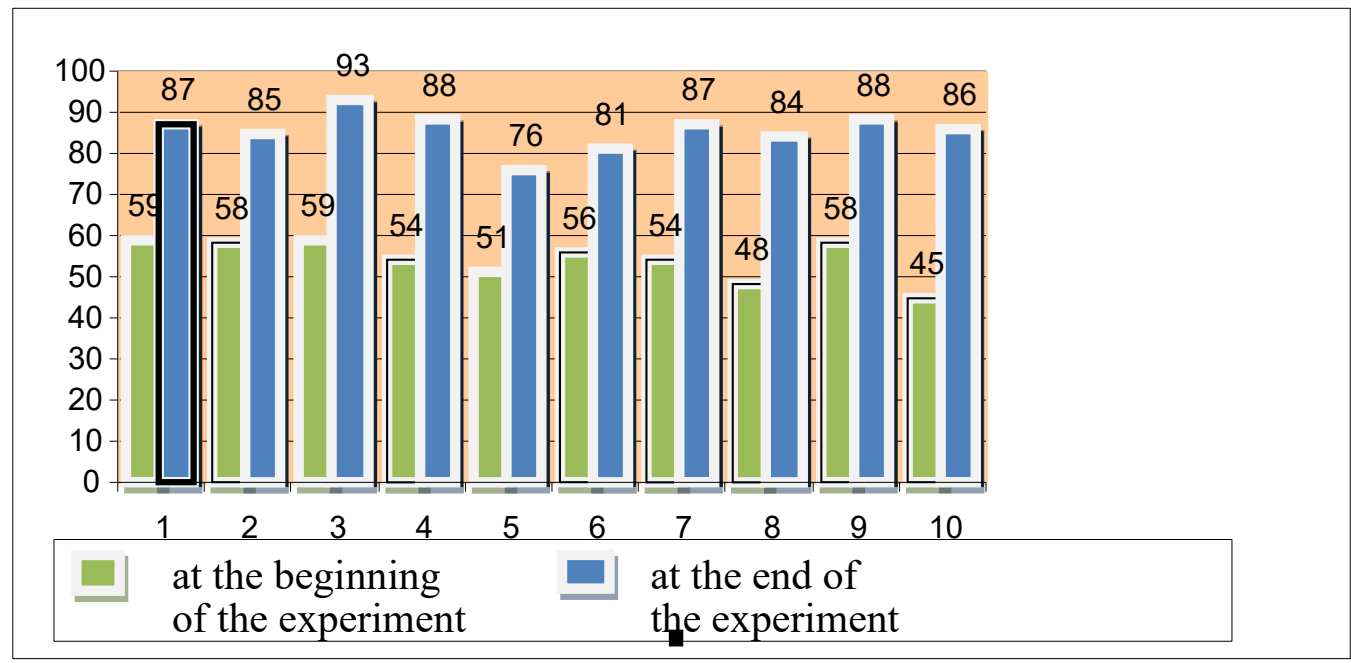

Figure 2. Indicators of children's ability to swim at the beginning and end of the study (in points).

1 - fear of water; 2 - immersion of the face in water; 3 - squats in water; 4 -jumping into the water; 5 - holding their breath under water; 6 - the ability to perform a "star"; 7 - the ability to push and glide; 8 - the ability to glide and work with their feet; 9 - the ability to glide and work with their hands; 10 - the ability to swim in coordination.

The results of the study suggest that we were able to significantly reduce the fear of water in junior schoolchildren, by a score of $28 \%(\mathrm{p}<0.001)$.

Analyzing the results obtained in connection with the mastery of swimming elements, we see that the smallest increase was obtained in the tests "holding one's breath under water" and "star" by $25 \%(\mathrm{p}<0.05)$, "immersion of the face in water" - 27\% $(\mathrm{p}<0.001)$, "the ability to glide and work with their hands" - 30\% $(\mathrm{p}<0.01)$.

Better results in terms of improved indicators during the second test were obtained in the control exercises "the ability to push and glide" - 33\% $(\mathrm{p}<0,05)$, "squats in the water" and "jumping into the water" by $34 \%(\mathrm{p}<0,05)$.

The highest growth rate was found in control exercises involving the ability to swim in coordination $-35 \%(\mathrm{p}<0.001)$ and the ability to glide and work with their feet $-36 \%$ (p $<0.05)$.

In order to determine the overall effectiveness of the use of folk games in the process of teaching swimming to junior schoolchildren, we calculated the coefficient of education of the children (according to V. Bespalko) on their ability to swim (table 2). 
The results of indicators of the value of the coefficient of education of children of junior school age in relation to the ability to swim

\begin{tabular}{|c|c|c|c|}
\hline Investigation stage & $\begin{array}{c}\text { The number of } \\
\text { junior } \\
\text { schoolchildren }\end{array}$ & Average point & $\begin{array}{c}\text { The value of the } \\
\text { learning } \\
\text { coefficient } \\
\text { by testing results }\end{array}$ \\
\cline { 1 - 1 } (the beginning of \\
the camp shift)
\end{tabular}

The results of testing junior schoolchildren at the beginning of the study indicate an insufficient initial level of swimming skills - the learning rate is 0.54 . At the end of the study, after the introduction of folk games into the system of teaching swimming to junior schoolchildren, the value of the learning coefficient associated with the test results is 0.85 , which corresponds to a high level of swimming skill development.

Conclusions and prospects for further research. The analysis of the test results showed a significant improvement in the indicators for all the control exercises, and the coefficient of children's education involving the ability to swim during the study increased by 0.31. The results obtained testify to the effectiveness of the introduction of adapted Ukrainian folk games into the method of teaching swimming to junior schoolchildren in outdoor waters. The comprehensive swimming exercise instruction gave children the opportunity to acquire new skills and abilities that greatly contribute to the children's safety in the water.

\section{References}

[1] Bulgakova, N. (2002). Meet Swimming. Moscow: ASTREL [in Russian].

[2] Makarenko, L. (1983). A Young Swimmer. Moscow: Physical Education and Sport [in Russian]. 
[3] Osokina, T. (1985). How to Teach Children to Swim. Moscow: Enlightenment [in Russian].

[4] Savchenko M. (2005). Swimming in Open Reservoirs: Educational and methodical Grant. Kirovohrad: RVV KDPU named after V. Vynnychenko [in Ukrainian].

[5] Parfenov V. (1978). Swimming. Textbook for Pedagogical Institutes. Kiev: High School [in Ukrainian].

[6] Skaliy O. (2002). Computer Technologies of Differentiation of the Process of Physical Education of Schoolchildren (on the Example of Swimming Training). Thesis for obtaining the Candidate Degree in Physical Training and Sport. Ternopil: TNPU of Vladimir Hnatiuk [in Ukrainian].

[7] Honchar I. (2006). Teaching Swimming Techniques: Technology of Training and Improvement [Textbook]. Odessa: [in Ukrainian].

[8] Shmareva, E. (2009). The Development of a Creative Personality in HealthImproving Swimming Classes. Endowment in the Field of Sports and Extreme Activities: Moscow: RGUFKSiT [in Russian].

[9] Kachurovskii D. (2009). Problems of Swimming in Ukraine: Zaporozhye [in Ukrainian].

[10] Obrazhey, O. (2017). Overcoming the Fear of Water at the Initial Stage of Learning to Swim. Physical Education, Sports and Health Culture in Modern Society, (1(37), 6671. https://doi.org/10.29038/2220-7481-2017-01-66-71 [in Ukrainian].

[11] Prystupa, Ye. (1999). Ukrainian National Outdoor Games, Entertainments and Entertainments: Methodology,Ttheory, Practice. Drogobych: Measurement. [in Ukrainian].

[12] Volchynskyi, A. (2009). The Ukrainian National Outdoor Games in the System of Physical Training of Preschool Children: Monograph. Lutsk: RBB "Tower" Volynsk National University of Lesya Ukrainka. [in Ukrainian].

[13] Tsos, A. (2000). Physical Training in Calendar Ceremonialism of Ukrainians: Monograph. Lutsk: Nadstir I [in Ukrainian].

[14] Levkiv, V. (1998). The Use of the Means of Ukrainian Folk Physical Culture in the Physical Education of Children of Junior School Age: Extended Abstract of Candidate's Thesis. Lviv: Lesya Ukrainka Volyn National University [in Ukrainian].

[15] Onopriienko, O. (2011). Means of Folk Physical Culture and Theoretical and Methodological Bases of their Pedagogical Classification. Psychological and Pedagogical Problems of Rural School (36), 218-223. 
[16] Mudryk, S. (1999). The Effectiveness of National Motional Games Application at the Physical Education Lessons in Junior School. Extended abstract of Candidate's Thesis. Lutsk: Lesya Ukrainka Volyn National University [in Ukrainian].

[17] Obrazhey, O. (2018). Peculiarities of Formation Smimming Training Process of Junior Schoolchildren in a Summer Camp. Physical Education, Sports and Health Culture in Modern Society, (3 (43), 56-62. https://doi.org/10.29038/2220-7481-2018-5662c. [in Ukrainian].

[18] Bespalko, V. (1968). Experience of Development and Use of Criteria of Quality of Assimilation of Knowledge. Moscow: Enlightenment [in Russian].

[19] Kucher, V., Grygus, I. (2013). The use of outdoor games and their effects on the body of schoolchildren. Pedagogics, psychology, medical-biological problems of physical training and sports. 1. 39-43. 